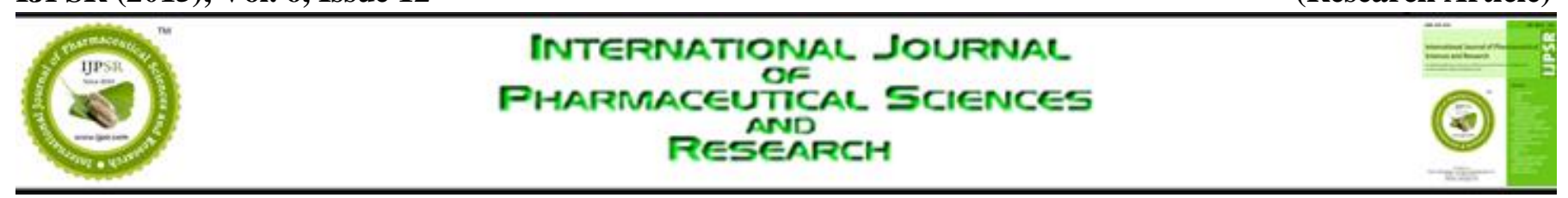

Received on 15 June, 2015; received in revised form, 11 July, 2015; accepted, 20 November, 2015; published 01 December, 2015

\title{
FORMULATION AND IN-VITRO EVALUATION OF FLOATING EFFERVESCENT TABLETS OF RANITIDINE HYDROCHLORIDE
}

Afshan Meherose * and G. Udaya Bhanu

Malla Reddy Institute of Pharmaceutical Sciences Maisammaguda, Secunderabad - 500014 Hyderabad, Telangana, India.

\section{Keywords:}

Ranitidine hydrochloride, Hydroxy propyl methyl cellulose (HPMC),

Xanthan gum, Guar gum and

Floating Effervescent matrix tablets.

\section{Correspondence to Author: \\ Afshan Meherose}

Assistant Professor

School of Pharmacy, Deccan,

Educational Trust, Darussalam,

Hyderabad, Telangana- 500001,

India.

E-mail: anasrasheed6500@gmail.com

\begin{abstract}
The main objective of the present work is to develop Floating Effervescent matrix tablets of Ranitidine hydrochloride using different polymers viz. hydroxy propyl methyl cellulose (HPMC), Xanthan gum and Guar gum. Varying ratios of drug and polymer like 1:0.6 and 1:1 were selected for the study. After fixing the ratio of drug and polymer for control the release of drug up to desired time, the release rates were modulated by combination of two different rate controlling material. After evaluation of physical properties of tablet, in-vitro buoyancy studies, Swelling index and in vitro release study were performed in $0.1 \mathrm{~N} \mathrm{Hcl}$ up to $12 \mathrm{hrs}$. Dissolution data was analyzed by Korsmeyer-Peppas power law expression and modified power law expression. It was observed that matrix tablets contained polymer blend of HPMC $\mathrm{K} 100 \mathrm{M} /$ Guar gum were successfully sustained the release of drug upto $12 \mathrm{hrs}$. Among all the formulations, formulation F9 which contains 50\% HPMC K100M and $50 \%$ of Guar gum has released the drug which follow Zero order kinetics via, swelling, diffusion and erosion. The release profile of formulation F9 was comparable with the marketed product. The FTIR study revealed that there was no chemical interaction between drug and excipients.
\end{abstract}

INTRODUCTION: The oral route is considered as the most promising route of drug delivery. Effective oral drug delivery may depend upon the factors such as gastric emptying process, gastrointestinal transit time of dosage form, drug release from the dosage form and site of absorption of drugs. Most of the oral dosage forms possess several physiological limitations such as variable gastrointestinal transit, because of variable gastric emptying leading to non-uniform absorption profiles, incomplete drug release and shorter residence time of the dosage form in the stomach.

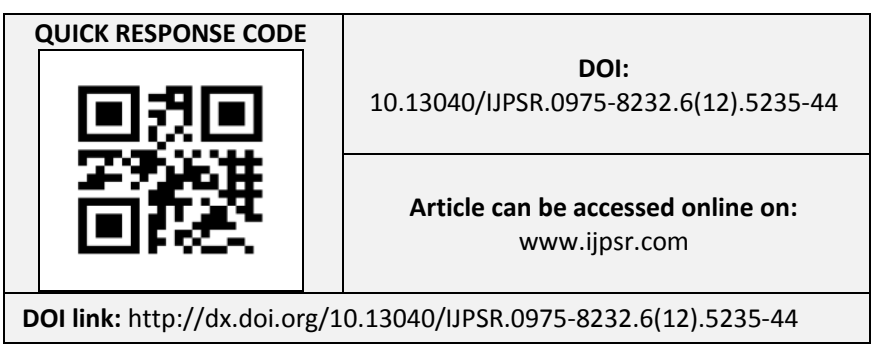

This leads to incomplete absorption of drugs having absorption window especially in the upper part of the small intestine, as once the drug passes down the absorption site, the remaining quantity goes unabsorbed. The gastric emptying of dosage forms in humans is affected by several factors because of which wide inter- and intra-subject variations are observed ${ }^{1-6}$. Since many drugs are well absorbed in the upper part of the gastrointestinal tract, such high variability may lead to non-uniform absorption and makes the bioavailability unpredictable. Hence a beneficial delivery system would be one which possesses the ability to control and prolong the gastric emptying time and can deliver drugs in higher concentrations to the absorption site (i.e. upper part of the small intestine).

The identification of new diseases and the resistance shown towards the existing drugs called 
for the introduction of new therapeutic molecules. In response, a large number of chemical entities have been introduced, of which some have absorption all over the gastrointestinal tract (GIT), some have absorption windows (i.e. absorption sites, especially the upper part of the small intestine) and some drugs have poor solubility in intestinal media. The drugs belonging to the second and third categories, and the drugs which are required for local action in the stomach, require a specialized delivery system. All the abiove requirements can be met and effective delivery of the drugs to the absorption window, for local action and for the treatment of gastric disorders such as gastro-esophageal reflux, can be achieved by floating drug delivery systems (FDDS). ${ }^{7-12}$

To date, a number of FDDS involving various technologies, carrying their own advantages and limitations were developed such as, single and multiple unit hydro dynamically balanced systems (HBS), single and multiple unit gas generating systems, hollow microspheres and raft forming systems ${ }^{12-17}$.

The hydrodynamic balanced system (HBS) also called Floating drug delivery system (FDDS) is an oral dosage form (capsule or tablet) designed to prolong the residence time of the dosage form within the GIT. It is a formulation of a drug with gel forming hydrocolloids meant to remain buoyant in the stomach contents. Drug dissolution and release from the dosage form retained in the stomach fluids occur at the $\mathrm{pH}$ of the stomach under fairly controlled conditions ${ }^{3}$. The retentive characteristics of the dosage form are not significant for the drugs that:

1. Are insoluble in intestinal fluids

2. Act locally

3. Exhibit site-specific absorption.

However, the system can be used for most of the drugs where controlled (sustained) release of the dosage form is desired by the oral route.

The formulation of the dosage form must comply with three major criteria for HBS.
It must have sufficient structure to form a cohesive gel barrier.

It must maintain an overall specific gravity less than that of gastric content.

It should dissolve slowly enough to serve as a "Reservoir" for the delivery system. ${ }^{18-22}$

\section{Drug Profile:}

Name: Ranitidine hydrochloride.

ii. Type: A non-imidazole blocker of those histamine receptors that mediate gastric secretion (H2 receptors). It is used to treat gastrointestinal ulcers.

\section{iii. Structure:}

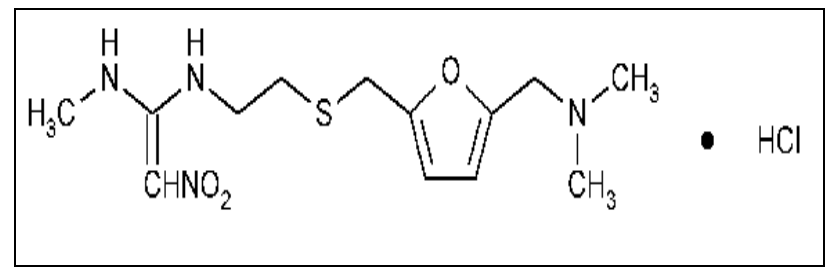

FIG.1: STRUCTURE OF RANITIDINE

\section{iv. Categories:}

Anti-Ulcer Agents, Histamine $\mathrm{H}_{2}$ Antagonists

\section{v. Chemical Formula: $\quad \mathrm{C}_{13} \mathrm{H}_{22} \mathrm{~N}_{4} \mathrm{O}_{3} \mathrm{~S}$}

\section{vi. IUPAC Name:}

dimethyl $[(5-\{[(2-\{[(E)-1$ - (methyl amino) $-2-$ nitroethenyl] amino $\}$ ethyl) sulfanyl] methyl $\}$ furan-2-yl) methyl]amine.

\section{MATERIALS AND METHODS:}

TABLE 1:MATERIALS USED IN THE STUDY

\begin{tabular}{ccc}
\hline S.No & $\begin{array}{c}\text { Active and inactive } \\
\text { pharmaceutical } \\
\text { ingredients }\end{array}$ & Suppliers \\
\hline 1 & Ranitidine Hydrochloride & $\begin{array}{c}\text { Zhaveri Pharmakem, } \\
\text { Mumbai }\end{array}$ \\
2 & Guar gum & FMC Biopolymer, USA \\
3 & Xanthan gum & Aqualon, USA \\
4 & Sodium bicarbonate & Colorcon, Goa \\
5 & Mannitol & DOW , USA \\
6 & Hydroxyl propyl methyl & Colorcon Asia Pvt. Ltd., \\
& cellulose & Goa \\
7 & (HPMC K100M) & Colorcon Asia Pvt. Ltd., \\
& Hydroxyl propyl methyl & Gollulose
\end{tabular}




\begin{tabular}{ccc}
\hline & (HPMC K4M) & \\
8 & Magnesium Stearate & LobaChemie \\
9 & Talc & LobaChemie \\
10 & Isopropyl alcohol & Colorcon, Goa \\
11 & Dicalcium phosphate & Colorcon, Goa \\
\hline
\end{tabular}

Preparation of standard solution of Ranitidine hydrochloride:

Stock solution: $100 \mathrm{mg}$ of Ranitidine $\mathrm{HCl}$ was weighed accurately and transferred into a $100 \mathrm{ml}$ volumetric flask. Then the volume was made upto $100 \mathrm{ml}$ using water.

Standard solution: $10 \mathrm{ml}$ of solution was withdrawn from the above stock solution and then made upto $100 \mathrm{ml}$ in another $100 \mathrm{ml}$ volumetric flask and this solution is considered as standard solution $(100 \mu \mathrm{g} / \mathrm{ml})$.

- From the above standard solution $0.5,1,1.5,2$, $2.5 \mathrm{ml}$ was withdrawn and diluted to $10 \mathrm{ml}$ to get $5,10,15,20,25 \mu \mathrm{g} / \mathrm{ml}$ concentration.
- The solutions were analyzed spectrophotometrically at $314 \mathrm{~nm}$ using UV visible spectrophotometer.

\section{Standard Calibration Curve:}

TABLE 2: STANDARD CALIBRATION CURVE

\begin{tabular}{ccc}
\hline S.No & Concentration $(\boldsymbol{\mu g} / \mathbf{m l})$ & $\begin{array}{c}\text { UV Absorbance at } \\
\mathbf{2 2 6} \mathbf{~ n m}\end{array}$ \\
\hline 1 & $0 \mu \mathrm{g} / \mathrm{ml}$ & 0.00 \\
2 & $5 \mu \mathrm{g} / \mathrm{ml}$ & $0.183 \pm 0.02$ \\
3 & $10 \mu \mathrm{g} / \mathrm{ml}$ & $0.358 \pm 0.02$ \\
4 & $15 \mu \mathrm{g} / \mathrm{ml}$ & $0.536 \pm 0.02$ \\
5 & $20 \mu \mathrm{g} / \mathrm{ml}$ & $0.710 \pm 0.02$ \\
6 & $25 \mu \mathrm{g} / \mathrm{ml}$ & $0.891 \pm 0.02$ \\
\hline
\end{tabular}

Formulation development:

Preparation of matrix tablets by wet granulation method: Different tablet formulations were prepared by wet granulation method.

\section{Formulation table:}

TABLE 1: FORMULATION TABLE

\begin{tabular}{ccccccccc}
\hline Ingredients(mg) & F1 & F2 & F3 & F4 & F5 & F76 & F7 & F8 \\
\hline API & 150 & 150 & 150 & 150 & 150 & 150 & 150 & 150 \\
HPMC K100M & 100 & - & - & - & 150 & - & - & - \\
Guar gum & - & 100 & - & - & - & 150 & - & - \\
HPMC K4M & - & - & 100 & - & - & - & 150 & - \\
Xanthum gum & - & - & - & 100 & - & - & - & 150 \\
Magnesium Steararte & 3 & 3 & 3 & 3 & 3 & 3 & 3 & 3 \\
Sodium bicarbonate & 50 & 50 & 50 & 50 & 50 & 50 & 50 & 50 \\
Talc & 2 & 2 & 2 & 2 & 2 & 2 & 2 & 2 \\
Mannitol & 85 & 85 & 85 & 85 & 35 & 35 & 35 & 35 \\
Isopropyl alcohol & 2 & 2 & 2 & 2 & 2 & 2 & 2 & 2 \\
Dicalcium phosphate & 8 & 8 & 8 & 8 & 8 & 8 & 8 & 8 \\
Total & 400 & 400 & 400 & 400 & 400 & 400 & 400 & 400 \\
\hline
\end{tabular}

TABLE 2: FORMULATION TABLE

\begin{tabular}{ccccccc}
\hline Ingredients(mg) & F9 & F10 & F11 & F12 & F13 & F14 \\
\hline API & 150 & 150 & 150 & 150 & 150 & 150 \\
HPMC K100M & 50 & 50 & 50 & - & - & - \\
Guar gum & 50 & - & - & 50 & 50 & - \\
HPMC K4M & - & 50 & - & 50 & - & 50 \\
Xanthum gum & - & - & 50 & - & 50 & 50 \\
Magnesium Steararte & 3 & 3 & 3 & 3 & 3 & 3 \\
Sodium bicarbonate & 50 & 50 & 50 & 50 & 50 & 50 \\
Talc & 2 & 2 & 2 & 2 & 2 & 2 \\
Mannitol & 85 & 85 & 85 & 85 & 85 & 85 \\
Isopropyl alcohol & 2 & 2 & 2 & 2 & 2 & 2 \\
Dicalcium phosphate & 8 & 8 & 8 & 8 & 8 & 8 \\
Total & 400 & 400 & 400 & 400 & 400 & 400 \\
\hline
\end{tabular}

Drug and excipient compatability studies by FTIR: The compatibility between the drug and polymer was evaluated by peak matching method.
There was no appearance or disappearance of the drug polymer mixture, which confirmed the 
absence of any chemical interactions between the drug and polymer.

\section{Evaluation of Precompression Blend:}

a) Particle size distribution: 10.35 grams of sample was taken and added to an assembly of sieves consisting ASTM sieve numbers \# 30, 40, 60, 80,100,120 base. Then assembly was closed and kept on sieve shaker and started analysis. Weights retained were checked for every 5 minutes and process was continued until variation in weights retained was not more than $5 \%$ or 0.1 gram. 20 minutes was set as end point based on the observation. Calculations were made to obtain cumulative percentage weight retained.

\section{b) Angle of Repose:}

The angle of repose of granules was determined by the funnel-method. The granules were allowed to flow through the funnel freely onto the surface. The diameter of the powder cone measured and angle of repose was calculated using the following equation.

$$
\tan \theta=\mathbf{h} / \mathbf{r}
$$

Where, $\mathrm{h}$ and $\mathrm{r}$ are the height and radius of the powder cone, $\theta$ is the angle of repose.

\section{c) Determination of Bulk Density and Tapped Density:}

The density apparatus was set for 100 tabs and after that the volume $\left(\mathrm{V}_{\mathrm{f}}\right)$ was measured and continued operation till the two consecutive readings were equal. The bulk density and the tapped density were calculated using the following formulae.

$$
\begin{gathered}
\text { Bulk density }=\mathrm{W} / \mathrm{V}_{0} \\
\text { Tapped density }=\mathrm{W} / \mathrm{V}_{\mathrm{f}}
\end{gathered}
$$

Where, $\mathrm{W}=$ Weight of the powder

$\mathrm{V}_{0}=$ Initial volume

$\mathrm{V}_{\mathrm{f}}=$ final volume

\section{d) Compressibility Index (Carr's Index):}

Carr's index (CI) is an important measure that can be obtained from the bulk and tapped densities. In theory, the less compressible a material the more flowable it is

$$
C I=(T D-B D) \times 100 / T D
$$

where, TD is the tapped density and BD is the bulk density.

\section{e) Hausner's Ratio:}

It is the ratio of tapped density and bulk density. Hausner found that this ratio was related to interparticle friction and, as such, could be used to predict powder flow properties (Lachman et al., 1987).

\section{Evaluation of Matrix Tablets:}

\section{a) Thickness:}

Twenty tablets from the representative sample were randomly taken and individual tablet thickness was measured by using digital vernier caliper. Average thickness and standard deviation values were calculated.

\section{b) Hardness:}

Tablet hardness was measured by using Monsanto hardness tester. From each batch six tablets were measured for the hardness and average of six values was noted along with standard deviations.

\section{c) Friability Test:}

From each batch, ten tablets were accurately weighed and placed in the friability test apparatus (Roche friabilator) at $25 \mathrm{rpm} / \mathrm{min}$ for $4 \mathrm{~min}$.

\section{d) Weight Variation Test:}

To study weight variation individual weights $\left(\mathrm{W}_{\mathrm{I}}\right)$ of 20 tablets from each formulation were noted using electronic balance. Their average weight $\left(\mathrm{W}_{\mathrm{A}}\right)$ was calculated.

\section{e) Drug Content (Assay):}

Ten tablets were weighed and taken into a mortar and crushed into fine powder. An accurately weighed portion of the powder equivalent to about $100 \mathrm{mg}$ of $\mathrm{TM}$ was transferred to a $100 \mathrm{~mL}$ volumetric flask containing $70 \mathrm{~mL}$ of $0.1 \mathrm{~N} \mathrm{HCl}$. It was shaken by mechanical means for $1 \mathrm{~h}$. Then it was filtered through a Whatman filter paper (No. 1) and diluted to $100 \mathrm{~mL}$ with $0.1 \mathrm{~N} \mathrm{HCl}$. From this resulted solution $1 \mathrm{~mL}$ was taken, diluted to $50 \mathrm{~mL}$ with $0.1 \mathrm{~N} \mathrm{HCl}$ and absorbance was measured against blank at $314 \mathrm{~nm}$.

\section{f) Swelling Index of Formulation:}

The swelling behaviour of floating tablets was measured by studying its weight gain (or) water uptake, water uptake was measured in terms of percent weight gain was given by equation. 


$$
\mathrm{WU}=(\mathrm{W} 1-\mathrm{W} 0) \times 100 / \mathrm{W} 0
$$

\section{g) In-vitro Buoyancy Studies:}

The tablet were placed in a beaker containing $0.1 \mathrm{n}$ $\mathrm{Hcl}$. The time required for the tablet to rise to the surface and float was determined as floating lag time. The total time for the tablet remain buoyant reported as floating time.

\section{h) In -vitro drug release characteristics:}

Drug release was assessed by dissolution test under the following conditions: $\mathrm{n}=3$, USP type II dissolution apparatus (paddle method) at $100 \mathrm{rpm}$ in $900 \mathrm{~mL}$ of $0.1 \mathrm{~N} \mathrm{HCl}$ for first 2 hours and the phosphate buffer $\mathrm{pH} 6.8$ from 3 to 12 hours, maintained at $37^{\circ} \mathrm{C} \pm 0.5^{\circ} \mathrm{C}$. An aliquot $(5 \mathrm{~mL})$ was withdrawn at specific time intervals and replaced with the same volume of prewarmed $\left(37^{\circ} \mathrm{C} \pm 0.5^{\circ} \mathrm{C}\right)$ fresh dissolution medium. The samples withdrawn were filtered through Whatman filter paper (No.1) and drug content in each sample was analyzed by UV-visible spectrophotometer at $314 \mathrm{~nm}$.

\section{RESULTS:}

Standard Calibration Graph of Ranitidine Hydrochloride:

TABLE 4: CALIBRATION GRAPH

\begin{tabular}{ccc}
\hline S.No & Concentration $\boldsymbol{\mu g} / \mathbf{m l}$ & UV Absorbance at $\mathbf{3 1 4} \mathbf{~ n m}$ \\
\hline 1 & 0 & 0.00 \\
2 & 5 & $0.183 \pm 0.02$ \\
3 & 10 & $0.358 \pm 0.02$ \\
4 & 15 & $0.536 \pm 0.02$ \\
5 & 20 & $0.710 \pm 0.02$ \\
6 & 25 & $0.891 \pm 0.02$ \\
\hline
\end{tabular}

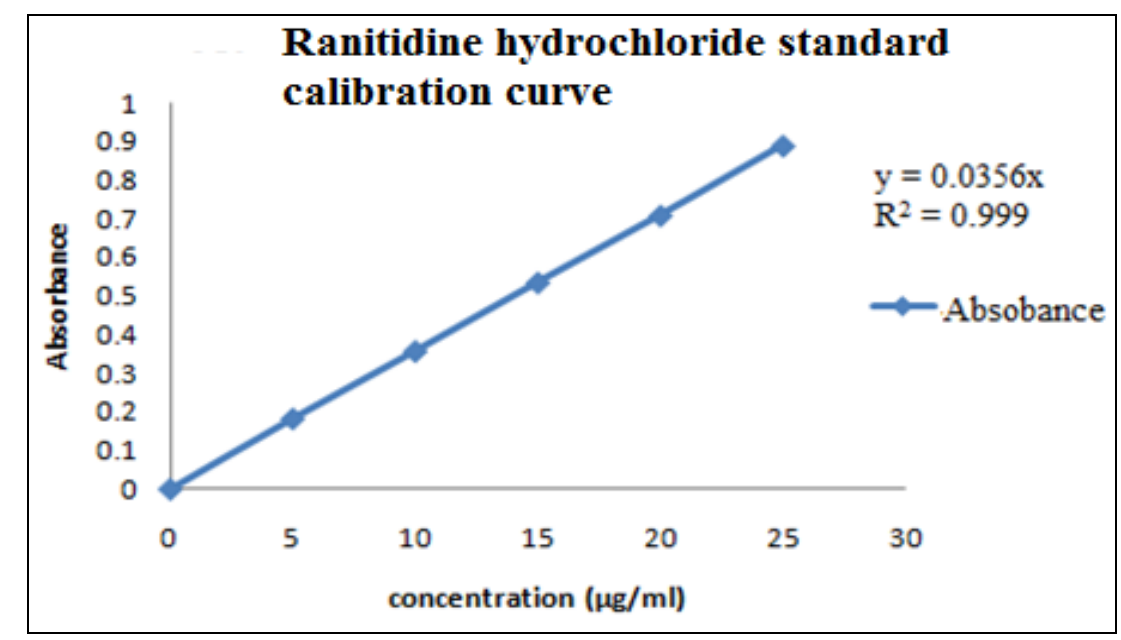

FIG.2: STANDARD CALIBRATION CURVE OF RANITIDINE HYDROCHLORIDE

Particle size distribution of drug:

TABLE 5: PARTICLE SIZE DISTRIBUTION OF DRUG

\begin{tabular}{ccccc}
\hline $\begin{array}{c}\text { Sieve Mesh } \\
\text { Number }\end{array}$ & $\begin{array}{c}\text { Sieve Size } \\
\text { Opening } \boldsymbol{\mu m}\end{array}$ & $\begin{array}{c}\text { Mass of } \\
\text { Sample } \\
\text { Retained On } \\
\text { Each Sieve(g) }\end{array}$ & $\begin{array}{c}\text { Percentage of } \\
\text { Sample } \\
\text { Retained on } \\
\text { Each Sieve (\%) }\end{array}$ & $\begin{array}{c}\text { Cumulative } \\
\text { Percentage Of } \\
\text { Sample Retained on } \\
\text { Each Sieve (\%) }\end{array}$ \\
\hline 30 & 841 & 0.08 & 0.772947 & 0.8 \\
40 & 425 & 0.06 & 0.57971 & 1.4 \\
60 & 250 & 0.05 & 0.483092 & 1.9 \\
80 & 180 & 0.41 & 3.961353 & 5.9 \\
100 & 150 & 1.55 & 14.97585 & 20.9 \\
120 & 130 & 2.62 & 25.31401 & 46.2 \\
Pan & - & 5.55 & 53.62319 & 99.8 \\
\hline
\end{tabular}


It was observed from table that from percentage cumulative size distribution it was found that around $2 \%$ of particles were above 250 microns and $98 \%$ were below 250 microns.

\section{Drug-excipient compatability by FTIR studies:}

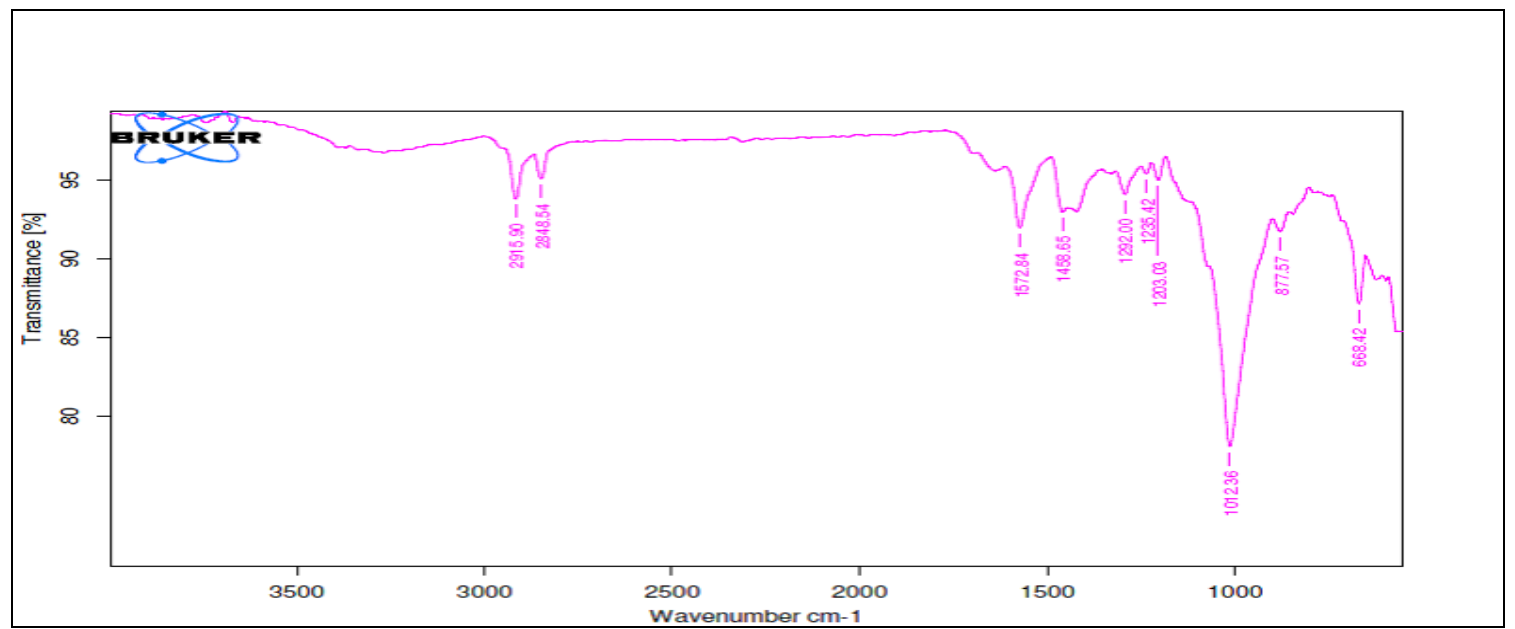

FIG.3: RANITIDINE WITH EXCIPIENTS DRUG AND POLYMER

\section{Characterization wet granulation blend:}

TABLE 6: CHARACTERIZATION WET GRANULATION BLEND.

\begin{tabular}{cccccc}
\hline Formulations & $\begin{array}{c}\text { Angle of repose } \\
\left({ }^{\circ}\right)\end{array}$ & $\begin{array}{c}\text { Bulk Density } \\
(\mathbf{g} / \mathbf{m L})\end{array}$ & $\begin{array}{c}\text { Tapped Density } \\
(\mathbf{g} / \mathbf{m L})\end{array}$ & $\begin{array}{c}\text { Carr's Index } \\
(\boldsymbol{\%})\end{array}$ & $\begin{array}{c}\text { Hausner's } \\
\text { ratio }\end{array}$ \\
\hline F1 & 25.49 & 0.214 & 0.251 & 14.74 & 1.17 \\
F2 & 26.24 & 0.308 & 0.364 & 16.07 & 1.18 \\
F3 & 29.05 & 0.276 & 0.322 & 14.28 & 1.16 \\
F4 & 26.97 & 0.341 & 0.388 & 12.11 & 1.13 \\
F5 & 29.25 & 0.324 & 0.376 & 13.82 & 1.16 \\
F6 & 32.27 & 0.320 & 0.397 & 19.39 & 1.24 \\
F7 & 33.65 & 0.521 & 0.629 & 21.5 & 1.20 \\
F8 & 33.21 & 0.518 & 0.627 & 26.38 & 1.21 \\
F9 & 26.56 & 0.422 & 0.506 & 15.38 & 1.19 \\
F10 & 28.75 & 0.481 & 0.572 & 15.90 & 1.18 \\
F11 & 27.33 & 0.475 & 0.566 & 16.07 & 1.19 \\
F12 & 26.27 & 0.487 & 0.561 & 13.19 & 1.15 \\
F13 & 26.43 & 0.412 & 0.483 & 22.45 & 1.17 \\
F14 & 24.77 & 0.488 & 0.537 & 9.12 & 1.10 \\
\hline
\end{tabular}

\section{It was observed from the table that the} formulation:

F1, F2, F3, F4, F5, F9, showed excellent flow properties and formulations F6, F7, F8 showed good flow properties and formulations F10, F11, F12, F13, 14 showed passable flow properties. Formulations F1, F3, F4, F5, F6, F10, F11 showed fair compressibility index and formulation F9 showed good compressibility index and formulation F8 showed poor compressibility index, formulations F7, F13 showed passable compressibility index. This outcome may be due to the use of lubricants or may be due to the method adopted.
Characterization of tablets prepaed by wet granulation:

It was observed from the table that the variation in weight was within the range of $\pm 7.5 \%$ complying with USP pharmacopoeial specifications. The thickness of tablets was found to be between 2.81$3.84 \mathrm{~mm}$. The hardness for all formulations was found to be between 5-6 kp. The friability was below $0.8 \%$ for all the formulations. The percentage drug content varied between 99.4-100.6 in different formulations indicating uniformity in the drug distribution among the tablets. 
TABLE 7: CHARACTERIZATION OF TABLETS PREPAED BY WET GRANULATION

\begin{tabular}{cccccc}
\hline F.Code & Hardness $\left(\mathbf{k g} / \mathbf{c m}^{2}\right) \dagger$ & Thickness $(\mathbf{m m}) \dagger$ & $\begin{array}{c}\text { Weight } \\
(\mathbf{m g}) \ddagger\end{array}$ & Friability $(\boldsymbol{\%})$ & Drug content * $(\%)$ \\
\hline F1 & $5.50 \pm 0.44$ & $3.22 \pm 0.17$ & $229.8 \pm 1.48$ & 0.48 & $98.25 \pm 1.37$ \\
F2 & $5.70 \pm 0.31$ & $3.37 \pm 0.25$ & $200.4 \pm 0.54$ & 0.42 & $95.28 \pm 0.80$ \\
F3 & $6.20 \pm 0.40$ & $3.14 \pm 0.80$ & $228.6 \pm 0.41$ & 0.28 & $99.12 \pm 2.47$ \\
F4 & $5.3 \pm 0.55$ & $3.20 \pm 0.20$ & $228.8 \pm 1.64$ & 0.52 & $97.35 \pm 0.43$ \\
F5 & $5.50 \pm 0.57$ & $3.08 \pm 0.66$ & $325.6 \pm 1.14$ & 0.56 & $95.28 \pm 0.80$ \\
F6 & $5.50 \pm 0.30$ & $3.33 \pm 0.25$ & $324.2 \pm 0.83$ & 0.58 & $99.53 \pm 1.87$ \\
F7 & $5.90 \pm 0.57$ & $3.24 \pm 0.71$ & $324.9 \pm 0.67$ & 0.47 & $93.28 \pm 1.99$ \\
F8 & $5.60 . \pm 0.60$ & $3.32 \pm 0.89$ & $324.0 \pm 0.43$ & 0.39 & $95.35 \pm 1.14$ \\
F9 & $5.50 \pm 0.60$ & $3.38 \pm 0.73$ & $325.5 \pm 0.80$ & 0.56 & $100.24 \pm 1.25$ \\
F10 & $6.10 \pm 0.31$ & $3.00 \pm 0.68$ & $324.2 \pm 0.83$ & 0.42 & $91.29 \pm 0.98$ \\
F11 & $6.30 \pm 0.37$ & $2.98 \pm 0.88$ & $326.1 \pm 0.93$ & 0.48 & $97.35 \pm 0.43$ \\
F12 & $5.90 \pm 0.65$ & $3.33 \pm 0.59$ & $325.8 \pm 0.38$ & 0.37 & $98.90 \pm 2.31$ \\
F13 & $6.00 \pm 0.50$ & $3.06 \pm 0.46$ & $324.2 \pm 0.83$ & 0.29 & $94.57 \pm 1.22$ \\
F14 & $5.90 \pm 0.57$ & $2.98 \pm 0.38$ & $327.2 \pm 0.92$ & 0.35 & $90.35 \pm 2.09$ \\
\hline
\end{tabular}

Dissolution studies:

TABLE 8: DISSOLUTION STUDIES OF MARKETED PRODUCT (ZANTAC150mg)

\begin{tabular}{cc}
\hline Sampling Time (hr) & $\begin{array}{c}\text { Cumulative \% Drug } \\
\text { Release }\end{array}$ \\
\hline 0 & 0 \\
0.25 & 12.5 \\
0.5 & 22.84 \\
1 & 34.23 \\
2 & 41.94 \\
4 & 54.36 \\
6 & 68.89 \\
8 & 82.3 \\
10 & 88.96 \\
12 & 96.45 \\
\hline
\end{tabular}

Post compression tests of marketed product Zantac (150mg):

TABLE 9: POST COMPRESSION TESTS

\begin{tabular}{cccc}
$\begin{array}{c}\text { Hardness } \\
(\mathbf{k g} / \mathbf{c m} \mathbf{2})\end{array}$ & Thickness $(\mathbf{m m})$ & Weight $(\mathbf{m g})$ & $\begin{array}{c}\text { Friability } \\
(\boldsymbol{\%})\end{array}$ \\
$3.37 \pm 0.74$ & $3.20 \pm 0.20$ & $127 \pm 0.83$ & 0.56 \\
\hline
\end{tabular}

In-vitro dissolution profile for the formulation F1, F2, F3 and F4:

TABLE 10: IN- VITRO DISSOLUTION PROFILE FOR THE FORMULATION F1, F2, F3 AND F4

\begin{tabular}{ccccc}
\hline Time in Hours & \multicolumn{4}{c}{ \% cumulative Drug Relaese } \\
& F1 & F2 & F3 & F4 \\
\hline 0 & 0 & 0 & 0 & 0 \\
0.25 & 8.25 & 18.32 & 28.52 & 16.32 \\
0.5 & 14.32 & 25.46 & 39.42 & 23.89 \\
1 & 23.96 & 32.83 & 54.52 & 30.42 \\
2 & 31.8 & 48.23 & 73.14 & 41.96 \\
4 & 39.43 & 65.43 & 89.76 & 69.76 \\
6 & 42.54 & 83.72 & 101.32 & 87.42 \\
8 & 57.85 & 99.83 & - & 99.97 \\
10 & 61.23 & - & - & - \\
12 & 72.85 & - & - & - \\
\hline
\end{tabular}


In-vitro dissolution profile for the formulation F9, F10, F11 and F12:

TABLE 12: IN-VITRO DISSOLUTION PROFILE FOR THE FORMULATION F9, F10, F11 AND F12

\begin{tabular}{ccccc}
\hline Time in & \multicolumn{4}{c}{ \% cumulative Drug Relaese } \\
\cline { 2 - 5 } Hours & F9 & F10 & F11 & F12 \\
\cline { 2 - 5 } 0 & 0 & 0 & 0 & 0 \\
0.25 & 13.72 & 17.32 & 12.23 & 14.92 \\
0.5 & 23.72 & 25.42 & 19.72 & 17.33 \\
1 & 36.23 & 33.27 & 34.89 & 22.86 \\
2 & 45.36 & 45.86 & 41.76 & 40.72 \\
4 & 58.96 & 62.36 & 59.6 & 61.56 \\
6 & 72.53 & 73.15 & 77.42 & 68.96 \\
8 & 85.16 & 81.28 & 85.42 & 90.2 \\
10 & 92.16 & 87.69 & 89.23 & 104.7 \\
12 & 99.8 & 91.23 & 93.76 & - \\
\hline
\end{tabular}

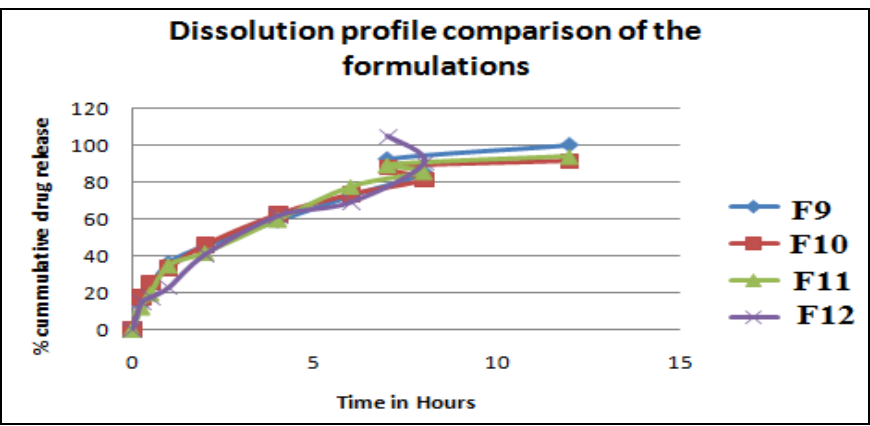

FIG.6: IN-VITRO DISSOLUTION PROFILE FOR THE FORMULATION F9, F10, F11 AND F12

In-vitro dissolution profile for the formulation F13 and F14

TABLE 13: IN-VITRO DISSOLUTION PROFILE FOR THE FORMULATION F13 AND F14

\begin{tabular}{ccc}
\hline Time in Hours & \multicolumn{2}{c}{ \% Cummulative Drug Release } \\
\cline { 2 - 3 } & F13 & F14 \\
\hline 0 & 0 & 0 \\
0.25 & 19.32 & 15.42 \\
0.5 & 27.48 & 18.32 \\
1 & 32.89 & 24.72 \\
2 & 41.72 & 38.92 \\
4 & 49.38 & 52.72 \\
6 & 52.73 & 66.23 \\
8 & 58.42 & 71.32 \\
10 & 63.23 & 101.32 \\
12 & 69.72 & - \\
\hline
\end{tabular}

In-vitro dissolution profile for the formulation innovator and optimized formulation (F9):

TABLE 14: IN-VITRO DISSOLUTION PROFILE FOR THE FORMULATION INNOVATOR AND OPTIMIZED FORMULATION (F9)

\begin{tabular}{ccc}
\hline Time in Hours & \multicolumn{2}{c}{ \% Cummulative Drug Release } \\
\cline { 2 - 3 } & Innovator & F9 \\
\hline 0 & 0 & 0 \\
0.25 & 12.5 & 13.72 \\
0.5 & 22.84 & 23.72 \\
1 & 34.23 & 36.23 \\
2 & 41.93 & 45.36 \\
4 & 54.36 & 58.96 \\
6 & 68.89 & 72.53 \\
8 & 82.3 & 85.16 \\
10 & 88.96 & 92.16 \\
12 & 96.45 & 99.8 \\
\hline
\end{tabular}

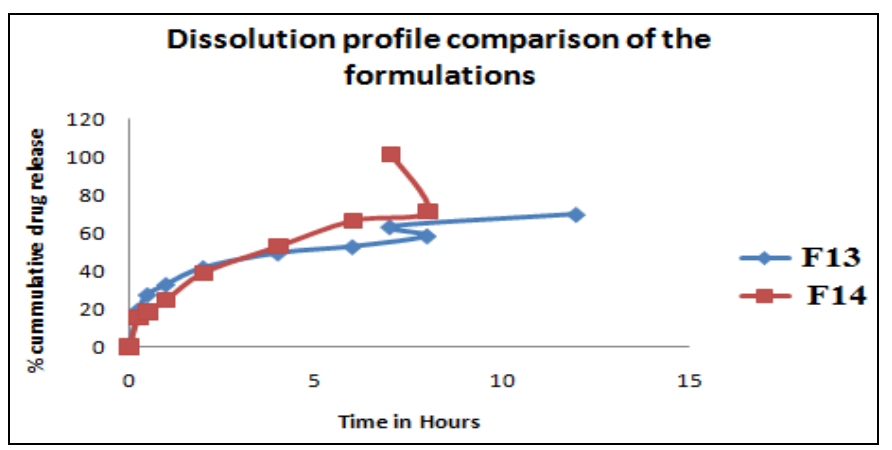

FIG.7: IN-VITRO DISSOLUTION PROFILE FOR THE FORMULATION F13 AND F14

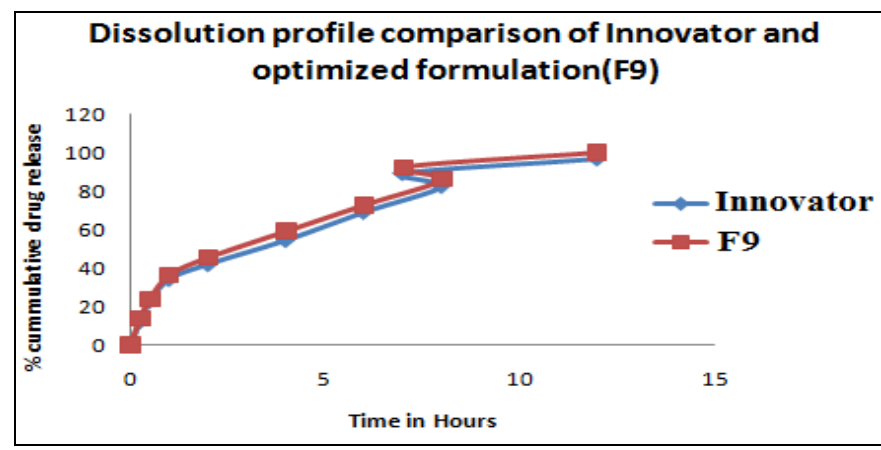

FIG.8: IN-VITRO DISSOLUTION PROFILE FOR THE FORMULATION INNOVATOR AND OPTIMIZED FORMULATION (F9)

\section{Release Kinetics:}

Zero order:

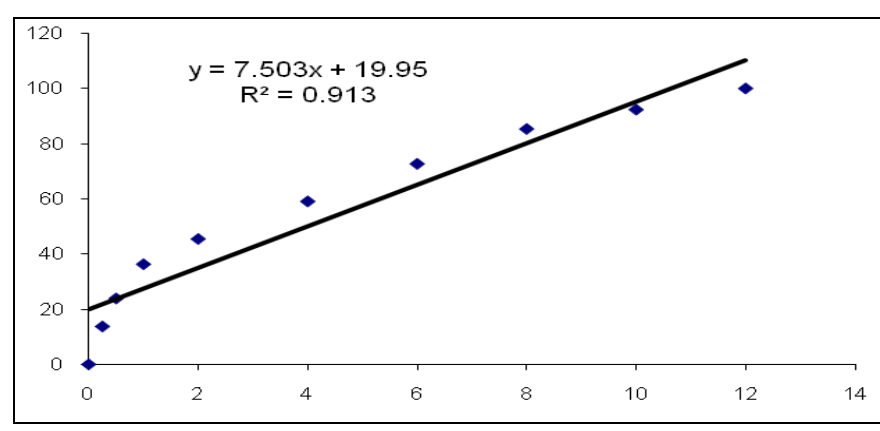

$\mathrm{x}$-axis-time (hrs)

$\mathrm{y}$-axis-cumulative percentage drug release

FIG.9: ZERO ORDER

First order:

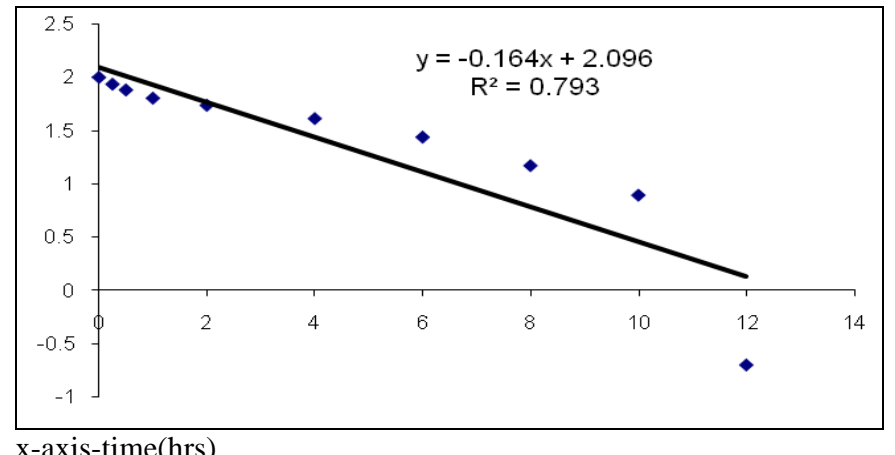

$\mathrm{y}$-axis-log cumulative percentage drug remaining

FIG.10: FIRST ORDER 


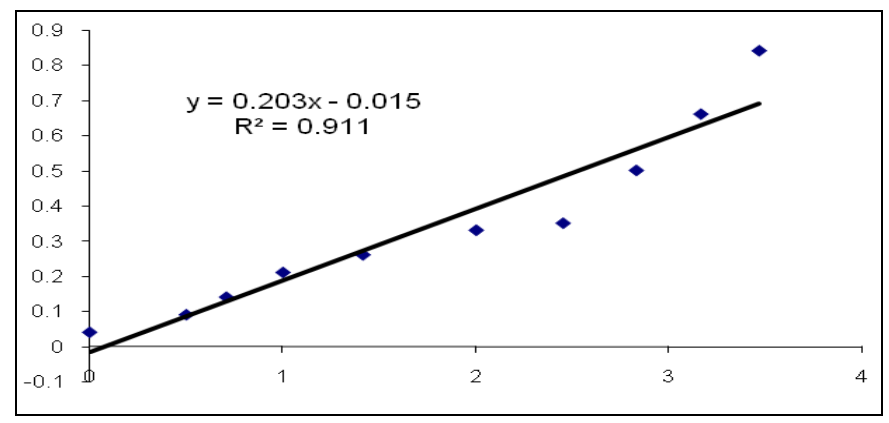

$\mathrm{x}$-axis-square root of time

$\mathrm{y}$-axis-cumulative percentage drug release.

FIG .11: HIGUCHI

\section{Korsemeyer and pappas:}

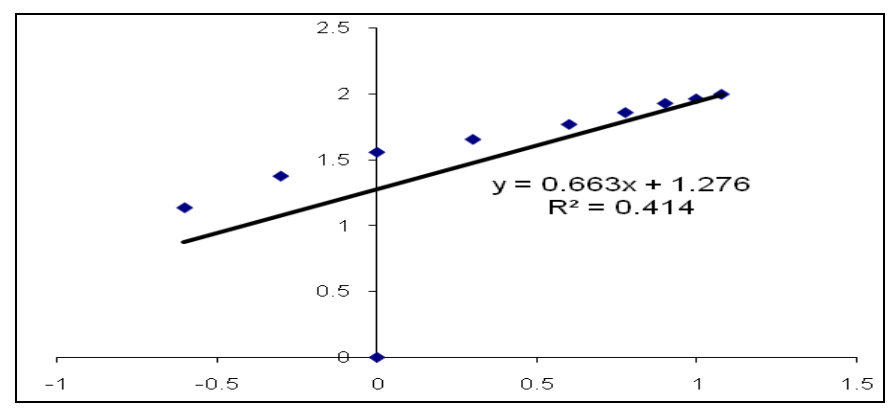

$\mathrm{x}$-axis-log time

$\mathrm{y}$-axis-log cumulative percentage drug release.

FIG.12: KORSEMEYER AND PAPPAS

\section{In-vitro buoyancy:}

TABLE 15: IN-VITRO BUOYANCY

\begin{tabular}{cc}
\hline Formulation Batch & Buoyancy in Minutes \\
\hline F1 & 10 \\
F2 & 15 \\
F3 & 30 \\
F4 & 45 \\
F5 & 85 \\
F6 & 100 \\
F7 & 110 \\
F8 & 140 \\
F9 & 655 \\
F10 & 470 \\
F11 & 490 \\
F12 & 370 \\
F13 & 310 \\
F14 & 455 \\
\hline
\end{tabular}

\section{Swelling Index:}

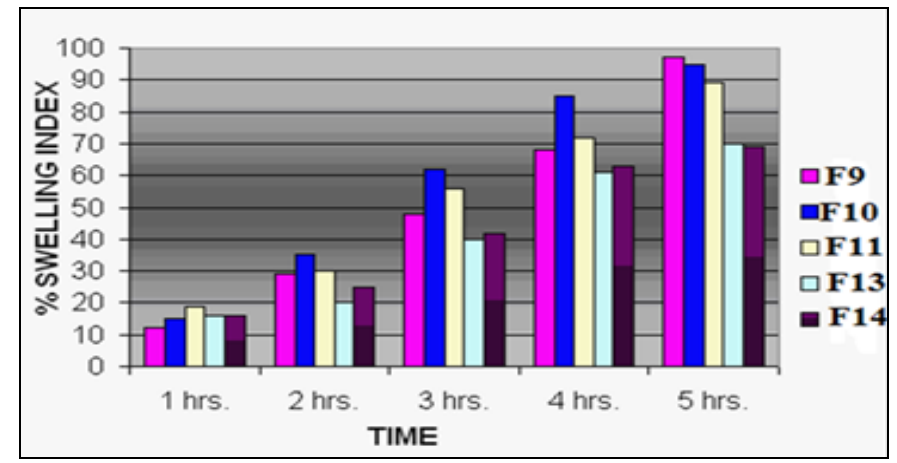

FIG.13: SWELLING INDEX
Similarity factor:

Similarity and difference factor

TABLE 16: SIMILARITY AND DIFFERENCE FACTOR

\begin{tabular}{|c|c|c|c|c|c|}
\hline $\begin{array}{l}\text { Time } \\
\text { (t) [in } \\
\text { Hours] }\end{array}$ & Innovator & Test (T) & Rt-Tt & $(\mathbf{R t}-\mathrm{Tt})^{2}$ & |Rt-Tt| \\
\hline 0 & 0.00 & 0.00 & 0.00 & 0.00 & 0.00 \\
\hline 1 & 24 & 25 & -1.00 & 1.00 & 1.00 \\
\hline 2 & 33 & 35 & -2.00 & 4.00 & 2.00 \\
\hline 3 & 49 & 51 & -2.00 & 4.00 & 2.00 \\
\hline 4 & 59 & 62 & -3.00 & 9.00 & 3.00 \\
\hline 6 & 70 & 73 & -3.00 & 9.00 & 3.00 \\
\hline 8 & 79 & 81 & -2.00 & 4.00 & 2.00 \\
\hline 10 & 84 & 87 & -3.00 & 9.00 & 3.00 \\
\hline 12 & 95 & 97 & -2.00 & 4.00 & 2.00 \\
\hline Sum & 493.00 & & & 44.00 & 18.00 \\
\hline \multicolumn{5}{|c|}{ Number of Time points or intervals (Excluding Zero) } & 7 \\
\hline \multicolumn{5}{|c|}{ Difference Factor - F1 [ Acceptance Criteria : 0 - 15] } & 3.65 \\
\hline \multicolumn{5}{|c|}{ Similarity Factor - F2 [ Acceptance Criteria : 50 - 100] } & 78.44 \\
\hline
\end{tabular}

CONCLUSION: The main goal of this work was to develop Floating Effervescent tablets of Ranitidine Hydrochloride. The formulation design was expected to provide sustained release of Ranitidine Hydrochloride from the dosage form to treat for peptic and duodenal ulcers. Total 14 formulations were prepared using HPMCK100M, HPMCK4M, Guargum, Xanthum gum and were evaluated for various parameters. According to work plan the prepared tablets were evaluated for Hardness, Thickness, Friability, Invitro Buoyancy, Swelling Index, Dissolution profile, Weight, Drug content.

As formulations (F1-F4) show undesired release profiles, so drug: polymer ratio changed to $1: 1$ by decreasing the ratio of Mannitol and weight adjusted to 400mg. Formulations (F5-F8) showed better release profile as that of (F1-F4).

Formulations (F9-F14) are taken in combination of polymers. These set of formulations shows prolonged when compared to (F1-F8). Formulation (F9) shows desired drug release for 12 hours due to the combination of polymers HPMC K100M and Guar gum.

From results it was observed that the In vitro dissolution profile of Sustained release matrix tablets containing Ranitidine hydrochloride from the formulation $\mathrm{F} 9$, drug release at $0,0.25,0.5,1$, $2,4,6,8,10,12 \mathrm{hr}$ was found to be $13.72 \%$, $23.72 \%, \quad 36.23 \%, \quad 45.36 \%, 58.96 \%, \quad 72.53 \%$, $85.16 \%, 92.16$ and $99.8 \%$ respectively. 
The floating effervescent tablets of Ranitidine Hydrochloride $150 \mathrm{mg}$ provided sustained drug release for $12 \mathrm{~h}$. From the results it was observed that the F9 formulation of Ranitidine Hydrochloride using Guargum and HPMC K100M as polymers was found to be the best formulation. Future scope was supposed to have pilot plant scale up, in-vivo evaluation and also industrial application of floating effervescent tablets of Ranitidine Hydrochloride.

\section{REFERENCES:}

1. Rouge.N, Buri.P, Doelker. E., "Drug absorption sites in the gastrointestinal tract and dosage forms for site-specific delivery", Int. J. Pharm., 1996, 136, 117-139.

2. Reddy, L., Murthy, R., "Floating dosage systems in drug delivery", Crit. Rev. Ther. Drug Carrier Syst., 2002, 19, 553-585.

3. Deshpande, A.A., Shah, N.H., Rhodes, C.T., Malick, W., "Development of a novel controlled release system for gastric retention", Pharm. Res., 1997, 14, 815-819.

4. Chien, Y.W., "Novel drug delivery system", Marcel Dekker, 2nd Edi. Rev. Expand., 50, 139-196.

5. Chungi, V.S., Dittert, L.W., Smith, R.B., "Gastrointestinal sites of furosemide absorption in rats", Int. J. Pharm., 1979, 4, 27-38.

6. Sheth, P.R., Tossounian, J., "The hydrodynamically balanced system (HBSTM): a novel drug delivery system for oral use", Drug Dev. Ind. Pharm., 1984, 10, 313-339.

7. Gutierrez-rocca, J., Omidian, H., Shah, K., "Progress in Gastroretentive drug delivery systems", Business Briefing, Pharmatech, 2003, 152-156.

8. Hou, S.Y., Cowles, V.E., Berner, B., "Gastric retentive dosage forms: a review", Crit. Rev. Ther. Drug Carrier Syst., 2003, 20(6), 459-97.

9. DebjitBhowmik, Chiranjib.B. "Floating Drug Delivery System" Der Pharmacia Lettre 2009, 1(2)199-218.

10. Manoj Goyal.., Floating Drug Delivery System., Journal of current pharmaceutical research 2011; 5(1):7-18
11. Cremer, K., "Drug delivery: gastro-remaining dosage forms", The Pharm. Journal 1997, 259, 108.

12. Garg, S., Shringi, S., "Gastroretentive drug delivery systems", Business briefing, Pharmatech, 5th edition,.. 2003, 160-166.

13. Robinson, J., Lee, R., "In Controlled drug delivery", 2nd edition, 1987, 418.

14. Vani R and Rasheed A: Formulation and evaluation of Hydrochlorothiazide and Ramipril Mouth Dissolving Tablet using different Superdisintegrants. Int J Pharm Sci Res 2014; 5(1): 207-12.doi: 10.13040/IJPSR. 09758232.5(1).207-12.

15. Rasheed A et al., Analytical Method Development and Validation for the Simultaneous Estimation of Aspirin, Clopidogrel Bisulphate and Atorvastatin Calcium in Tablet Dosage Form. American Journal of PharmTech Research 2014.

16. Rasheed A, Fathima I and Altaf M: Attention Deficit Hyperactivity Disorder (ADHD): An Overview. Int J Pharm Sci Res 2013; 4(4); 1669-1683.

17. Vani R. et al., Validation and Derivative Spectroscopy of Prasugrel $\mathrm{HCl}$ in Bulk and Formulation. American Journal of PharmTech Research 2013.

18. R. Vani, B. Vijaya Kumar, Anas Rasheed; Analytical Development and Formulation of Ramipril and Hydrochlorothiazide in Combination With Selective Excipients, R. Vani, et al. Int J Pharm 2013; 3(2): 348-35.

19. Rasheed A and Farhat R: Combinatorial Chemistry. Int J Pharm Sci Res 2013: 4(7); 2502-2516. doi: 10.13040/IJPSR. 0975-8232.4(7).2502-16.

20. Rasheed A and QasimMd: A Review of Natural Steroids and their Applications. Int J Pharm Sci Res. 2013; 4(2); 520-531.

21. Altaf et al. Drug Utilisation Evaluation Of Antihypertensives In Geriatric Patients In A Tertiary Care Hospital, Int J Pharm PharmSci, Vol 6, Issue 9, 261-264.

22. Anas Rasheed Mohammed Altaf et al. A Cross-Sectional Study of Analysis of Knowledge of Diabetes In Diabetic Patients And Patient Counselling In Princess Esra Hospital, IOSR Journal of Pharmacy (e)-ISSN: 2250-3013, (p)-ISSN: 2319-4219 , www.iosrphr.org Volume 4, Issue 4 (April 2014), Pp 80-93.

How to cite this article:

Meherose A and Bhanu GU: Formulation and In-vitro Evaluation of Floating Effervescent Tablets of Ranitidine Hydrochloride. Int J Pharm Sci Res 2015; 6(12): 5235-44.doi: 10.13040/IJPSR.0975-8232.6(12).5235-44.

All @ 2013 are reserved by International Journal of Pharmaceutical Sciences and Research. This Journal licensed under a Creative Commons Attribution-NonCommercial-ShareAlike 3.0 Unported License.

This article can be downloaded to ANDROID OS based mobile. Scan QR Code using Code/Bar Scanner from your mobile. (Scanners are available on Google Playstore) 